\title{
Spatial variation of population size structure of selected riparian tree species in the Okavango Delta, Botswana
}

\author{
Gaolathe Tsheboeng \& Mike Murray-Hudson
}

\begin{abstract}
Transpiration by riparian trees in the Okavango Delta (Botswana) creates a salinity gradient which facilitates continuous water movement from the swamps to the islands. This leads to salt accumulations underneath islands which minimizes surface water salinity. The aim of this study was to investigate spatial variation in population size structure of riparian tree species in the Delta. It was hypothesized that riparian tree population structure will vary spatially due to different hydrological conditions. Riparian vegetation was surveyed in Boro, Santawani, Moremi, Vumbura and Seronga from a total of 75 plots measuring $20 \mathrm{~m}$ x $50 \mathrm{~m}$. Species chosen for this study in terms of their dominance were Croton megalobotrys Müll. Arg, Philenoptera violacea (Klotzsch) Schrire, Diospyros mespiliformis Hochst. Ex A.DC and Acacia nigrescens Oliv. Diameter at breast height (dbh) was measured for tree individuals with stem diameter $>2.5 \mathrm{~cm}$. Linear regression analysis was used to infer population size class distribution of each species. Croton megalobotrys Müll. Arg showed a reverse J size class distribution (SCD) pattern in Boro, Santawani and Vumbura while it showed a bell shaped pattern in Moremi. Philenoptera violacea (Klotzsch) Schrire showed an irregular size class distribution pattern with some missing size classes in Boro and Santawani while it showed a reversed $\mathbf{J}$ shaped size class distribution pattern with more individuals in the lower size classes in Vumbura. Diospyros mespiliformis Hochst. Ex A.DC showed a U shaped SCD pattern in Boro and irregular pattern in Seronga and Vumbura. Acacia nigrescens Oliv showed irregular SCD pattern with some missing size classes in Boro and Santawani and reverse $\mathbf{J}$ shaped SCD pattern with more individuals in the lower size classes in Seronga.
\end{abstract}

Keywords: diameter at breast hight (dbh); Okavango; recruitment; size class distribution (SCD); species.

Variação espacial da estrutura de tamanho da população de espécies selecionadas de árvores ribeirinhas no delta do Okavango, Botsuana

Resumo: A transpiração de árvores ribeirinhas no delta do Okavango, Botsuana, cria um gradiente de salinidade que facilita o movimento contínuo de água dos pântanos para as ilhas. Isto leva a acumulações de sal debaixo das ilhas que minimizam a salinidade da água de superfície. O objetivo deste estudo foi investigar a variação espacial na estrutura de tamanho da população de espécies de árvores ribeirinhas no delta. Postula-se que a estrutura da população de árvores ribeirinhas irá variar espacialmente devido à diferentes condições hidrológicas. A vegetação ribeirinha foi monitorada em Boro, Santawani, Moremi, Vumbura e Seronga de um total de 75 terrenos de $20 \mathrm{~m} \times 50 \mathrm{~m}$. As espécies escolhidas para esse estudo, em termos de sua posição dominante foram Croton megalobotrys Müll. Arg, Philenoptera violacea (Klotzsch) Schrire, Diospyros mespiliformis Hochst. Ex A.DC e Acacia nigrescens Oliv. O diâmetro à altura do peito $(\mathrm{DBH})$ foi medido em arbóreas com diâmetro do caule maior que $2.5 \mathrm{~cm}$. A análise de regressão linear foi utilizada para inferir a distribuição de classe por tamanho da população de cada espécie. A Croton megalobotrys Müll. Arg mostrou um padrão de distribuição de classe reverso de tamanho J (SCD) em Boro, Santawani e Vumbura enquanto mostrou um padrão em forma de sino em Moremi. A Philenoptera violacea (Klotzsch) Schrire mostrou um padrão irregular de distribuição de classe de tamanho, com algumas classes de tamanho faltando em Boro e Santawani, enquanto mostrou uma forma padrão de distribuição revertida de classe de tamanho J, com mais indivíduos nas classes de tamanho inferiores em Vumbura. A Diospyros mespiliformis Hochst . Ex A.DC mostrou um padrão SCD em forma de U em Boro e padrão irregular em Seronga e Vumbura. A Acacia nigrescens Oliv mostrou um padrão SCD irregular com algumas classes de tamanho faltando em Boro e Santawani e reverse J shaped SCD pattern com mais indivíduos nas classes de tamanho inferiores em Seronga.

Palavras-chave: diâmetro à altura do peito (DBH); distribuição por classe de tamanho (SCD); espécie; Okavango; recrutamento.

Received: 15 August 2013 - Accepted: 19 December 2013

\section{Introduction}

Riparian vegetation communities are transition zones between terrestrial and aquatic systems (Naiman et al. 1993).
They play a significant role due to their provision of ecosystem services and products to both human and animal populations. Ecosystem services performed by riparian tree species include primary production which produces food, nutrient cycling (Murkin 1998) and water purification through the process of evapotranspiration (McCarthy et al. 1994). Riparian tree species hold the soil together through 
their roots which helps to reduce erosion due to floods (Carter 1996). Riparian habitats serve as corridors and connecting elements which help to maintain regional diversity (Naiman et al. 1993). In the Okavango Delta, though, riparian tree habitats are frequently fragmented by floodplains and channels (McCarthy et al. 1994, Gumbricht et al. 2004). Although they do not form continuous corridors, they are also significant in maintaining local diversity. They provide habitat to primates (monkeys and baboons), birds, bats, insects and snakes and provide forage to both grazing and browsing animals (Skarpe et al. 2004). Trees provide timber which is used for building human shelter (van der Valk 2006). In the Okavango Delta tree species such as Diospyros mespiliformis Hochst. Ex A.DC are also used for the construction of traditional canoes which are used as a mode of transport by the local riparian communities (Heath \& Heath 2009).

The Okavango Delta is characterized by riparian tree-covered islands which play a significant role in the sequestration of potentially toxic solutes (McCarthy et al. 2012). The islands serve as a sink for dissolved solutes. Evapotranspiration by riparian trees lowers the water table under the islands relative to the water surface of the surrounding swamps. This creates a gradient which facilitates continuous movement of water from the swamps to the islands. As the trees transpire they leave dissolved solutes behind resulting in salinity increase in the groundwater. As a result of this, salt accumulations occur underneath islands and minimize surface water salinity (McCarthy et al. 1994). Similar processes are beginning to be identified in other sub-tropical major wetlands, such as the Everglades (e.g., Wetzel et al. 2005, Sullivan et al. 2010). In the context of the Okavango Delta, this is a critical ecological process for the long-term sustainability of the system (McCarthy et al. 1993).

Globally, riparian tree species are threatened by loss due to deforestation for agriculture (Reddy \& Gale 1994), climate change (Seavy et al. 2009) and invasive species (Cronk \& Fennessy 2001). In Botswana there is a policy framework designed to conserve and protect the Okavango Delta. These include the National Conservation Strategy (Matiza \& Chabwela 1992), the Botswana National Wetlands Policy and Strategy of 1999 and the Okavango Delta Management Plan which attempt to engage the public as active participants in wetland manage-

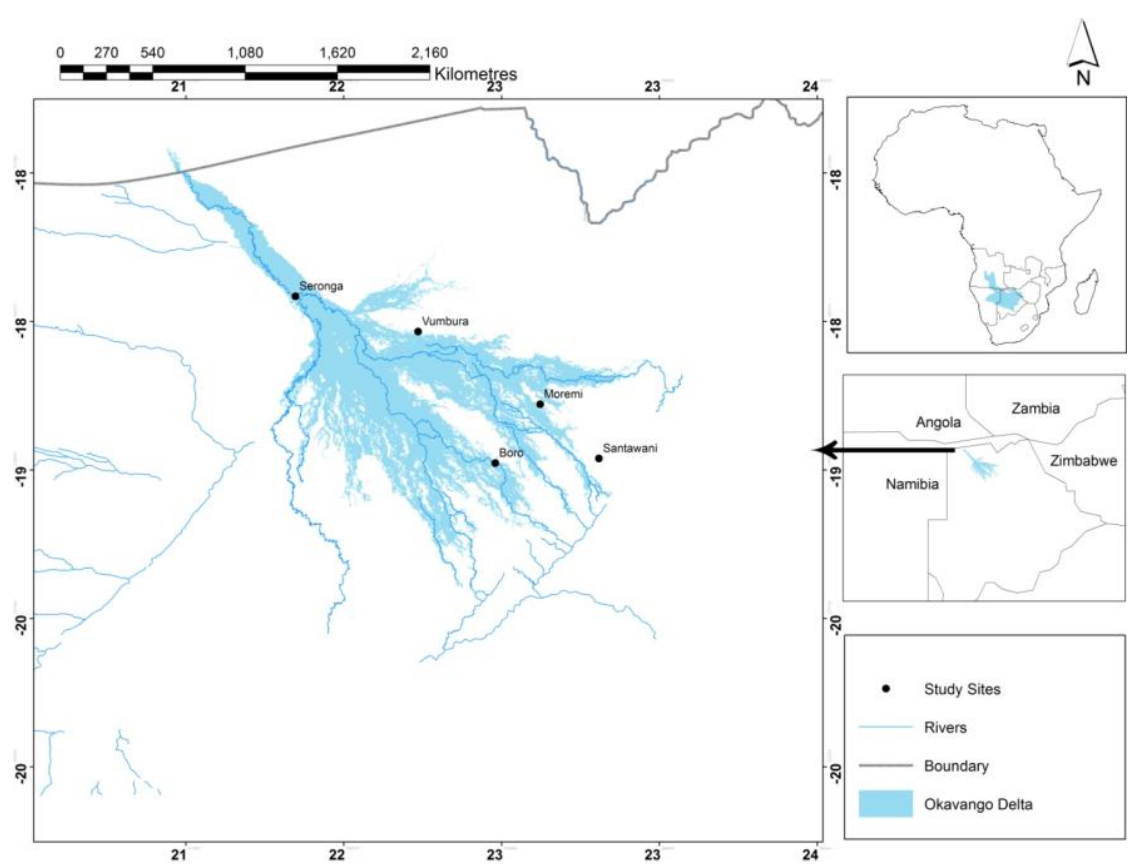

Fig. 1: The map of the Okavango Delta showing study sites

ment through the utilization of their indigenous knowledge and local institutions (Jansen \& Madzwamuse 2003). The Okavango Delta is also a declared Ramsar site, a wetland of international importance. Despite these efforts to conserve the Delta's biodiversity and ecology, the threats of deforestation, climate change and invasion by alien species persist, and as human populations around the periphery of the Delta grow, these damaging activities increase. An additional threat is increasingly posed by a large and rapidly growing population of African elephant, Loxodontus africanus (Natural Resources and People, 2007). Given the critical ecological function of the riparian woodlands, little can be done to ensure the sustainability of the Delta and its ecosystem processes and services without better knowledge of the current status and trends of tree populations. The information could also be used in modeling the possible future of the Okavango Delta in the context of vegetation resources utilization, climate change and basin development. In order for the tree species to be sustainably used their ecology has to be understood together with the ecological consequences of that use (Naiman et al. 1993). While several authors (e.g. Walker et al. 1986, Jones et al. 1994, Sop et al. 2011, Gurnman et al. 2012) characterized the spatial variation of riparian tree species population structure elsewhere, in the Okavango Delta this has not been done. Previous studies in the Okavango Delta only classified riparian tree species in relation to local environmental gradients in specific locations (Ellery et al. 1993, Ringrose \& Matheson 2001).

The aim of this study was to investigate the spatial variation of population structure of selected riparian tree species in the Okavango Delta. Variation of riparian tree species population structure was studied in sites selected along hydrological (flooding) gradients. Flooding has been found to be the overriding factor influencing the vegetation ecology of the Okavango Delta (Ellery et al. 1993). The effects of other influences, for example those of elephants and fire were inferred based on field observations.

\section{Materials and Methods}

\section{Study area}

The study was conducted in Seronga (22 $2^{\circ} 7^{\prime} 8^{\prime \prime} \mathrm{E}, 18^{\circ} 48^{\prime} 42^{\prime \prime} \mathrm{S}$ representing the Upper panhandle), Boro $\left(23^{\circ} 9^{\prime} 13^{\prime \prime E}\right.$, $19^{\circ} 32^{\prime} 27^{\prime \prime} \mathrm{S}$ representing the lower Delta), Santawani $\left(23^{\circ} 37^{\prime} 8^{\prime \prime E}, 19^{\circ} 32^{\prime} 11^{\prime \prime S}\right.$, representing the lower Delta), Vumbura $\left(19^{\circ} 17^{\prime} 9^{\prime \prime} \mathrm{S}\right.$, representing the northernDelta) and Moremi game reserve $\left(23^{\circ} 22^{\prime} 38^{\prime \prime} \mathrm{E}\right.$, also representing the lower Delta) (Fig. 1 and Table 1). Selection of the study sites in the upper, middle and lower parts of the Delta was designed to allow comparison of the population structure of riparian trees from regions exposed to different hydrological regimes. 
Table 1: Characterization of selected study areas based on field observations.

\begin{tabular}{|c|c|c|c|}
\hline Study area & Habitat type & Land use activity & Examples of herbivores present \\
\hline Santawani & Dryland & $\begin{array}{l}\text { Agriculture, Tourism, wildlife } \\
\text { habitat and human settlement }\end{array}$ & Giraffe, Elephant, Buffalo and Impala \\
\hline Moremi & Dryland & Tourism, wildlife habitat & Buffalo, Elephant and Impala \\
\hline Boro & $\begin{array}{l}\text { Permanently flooded, seasonally } \\
\text { flooded and dryland }\end{array}$ & $\begin{array}{l}\text { Tourism, agriculture, human settle- } \\
\text { ment and wildlife habitat }\end{array}$ & Cattle, Elephant, Impala and Buffalo \\
\hline Vumbura & $\begin{array}{l}\text { Permanently flooded, seasonally } \\
\text { flooded and dryland }\end{array}$ & Tourism and wildlife habitat & Buffalo, Elephant, Kudu and Impala \\
\hline Seronga & $\begin{array}{l}\text { Permanently flooded, seasonally } \\
\text { flooded and dryland }\end{array}$ & $\begin{array}{l}\text { Agriculture, Tourism, agriculture } \\
\text { and wildlife habitat }\end{array}$ & $\begin{array}{l}\text { Cattle, Elephant, Impala, Donkeys and } \\
\text { Goats }\end{array}$ \\
\hline
\end{tabular}

The Okavango Delta flood pulse originates from the Angolan highlands, arrives in the Upper Panhandle region between March and April (Björkvald \& Boring 2002) and reaches the distal regions between May and October (McCarthy et al. 2005). The Delta experiences both intra and inter annual flood variation (Wolski et al. 2006). Inter-annual flood variation refers to the differences in flooding magnitude between two or more years (Björkvald \& Boring 2002). Rainfall in the Okavango Delta ranges between a high of $550 \mathrm{~mm}$ in Shakawe (Wilson \& Dincer 1976 ) to a low of $450 \mathrm{~mm}$ in Maun (Bonyongo \& Mubyana 2004).

Common riparian tree species found in the Okavango Delta include Diospyros mespiliformis, Garcinia livingstonei $\mathrm{T}$. Anderson, Ficus natalensis Hochst, F. sycomorus L, Hyphaene petersiana Mart and Croton megalobotrys Müll. Arg (Ellery et al. 1993). Other common woody tree species found in the Okavango Delta include Acacia tortilis (Forsk) Hayne, A. erioloba E. Meyer and Colophospermum mopane (J. Kirk ex Benth) J. Kirk ex J. Léonard (Ringrose \& Matheson 2001), but these are restricted to dryland areas or relict floodplains which do not receive water under the prevailing hydroclimatic conditions. Tree species common to all sites were selected for the study.
These were C. megalobotrys, A. nigrescens, D. mespiliformis and $P$. violacea (Table 2). This enabled comparison of their population structure between different sites.

\section{Vegetation sampling}

Riparian vegetation sampling was conducted between February 2012 and April 2013 from randomly selected plots measuring $20 \mathrm{~m} \times 50 \mathrm{~m}$. In each plot the circumference $(>15 \mathrm{~cm})$ was measured from tree individuals (Sop et al. 2011) at $1.3 \mathrm{~m}$ above ground. For multi-stemmed trees, circumferences of the stems were summed up (Sop et al. 2011).

\section{Data analysis}

The diameter for individual trees was computed from the circumference. A total of 75 plots were sampled. Tree species from each study site were categorized into 8 dbh classes namely 0-10, 10-20, 20-30, $30-40,40-50,50-60,60-70$ and $>70 \mathrm{~cm}$. The method for inferring recruitment status of different plant species followed Shackleton et al (1993). Recruitment status of each species was determined by analyzing the slope of a linear regression of dbh size classes. Dbh midpoint (mi) was used as the independent variable while the density of individuals (Ni) in each dbh class was used as the dependent variable. Ni was transformed by $\ln (\mathrm{Ni}+1)$ since some classes had zero individuals. The regression was then done using $\ln (\mathrm{Ni}+1)$ and $\ln (\mathrm{mi})$. Negative slopes indicated ongoing recruitment with more individuals in smaller size classes than in larger size classes while positive slopes indicated little recruitment or possibly episodic recruitment (Helm \& Witkowski 2012).

\section{Results}

C. megalobotrys showed a reverse $\mathrm{J}$ size class distribution with more individuals in the lower size classes indicating stable populations in Boro (Figure 2A) with a slope coefficient of -3.78 and $\mathrm{R}^{2}$ of 0.84 indicating strong recruitment (Table 3), Santawani (Figure 2B) and Vumbura (Figure 2C) also with a strong recruitment indicated by high negative slope coefficient and $\mathrm{R}^{2}$ (Table 3 ) while a bell shaped pattern for populations in Moremi indicated an unstable population (Figure 2D) but apparently also with strong recruitment as indicated by both high negative coefficient and $\mathrm{R}^{2}$ (Table 3).

Table 2: Characteristics of riparian tree species selected for study in the Okavango Delta, Botswana (after Ellery et al. 1993, Heath \& Heath 2009). *Average height of fully grown tree.

\begin{tabular}{|c|c|c|c|c|c|c|}
\hline Tree species & Family & $\begin{array}{l}\text { Deciduous / } \\
\text { Evergreen }\end{array}$ & Distribution & $\begin{array}{l}\text { Mode of re- } \\
\text { production }\end{array}$ & Height $^{\star}$ & Uses \\
\hline D. mespiliformis & Ebenaceae & Evergreen & $\begin{array}{l}\text { Sandy soils close to } \\
\text { water }\end{array}$ & Seed & $20 \mathrm{~m}$ & $\begin{array}{l}\text { Fruits eaten, Canoe and furniture } \\
\text { construction }\end{array}$ \\
\hline A. nigrescens & Leguminosae & Deciduous & $\begin{array}{l}\text { Dry woodland and } \\
\text { island edges }\end{array}$ & Seed & $18 m$ & $\begin{array}{l}\text { Fire wood, Fence posts and Furni- } \\
\text { ture }\end{array}$ \\
\hline P. violacea & Leguminosae & Deciduous & $\begin{array}{l}\text { Dry woodland and } \\
\text { island edges }\end{array}$ & Seed & $10 \mathrm{~m}$ & Canoe construction \\
\hline C. megalobotrys & Euphorbiaceae & Evergreen & $\begin{array}{l}\text { Floodplain margins } \\
\text { and on fringes of } \\
\text { islands }\end{array}$ & Seed & $15 \mathrm{~m}$ & $\begin{array}{l}\text { Fruits mixed with bark to treat } \\
\text { malaria, Fruits mixed with vegeta- } \\
\text { ble to treat wounds }\end{array}$ \\
\hline
\end{tabular}


Table 3: Regression analysis slope coefficients for different tree species populations in the study sites.

\begin{tabular}{llll}
\hline Tree species & Site & Slope coefficient & $\mathbf{R}^{\mathbf{2}}$ \\
\hline C. megalobotrys & Boro & -3.78 & 0.84 \\
& Santawani & -2.95 & 0.80 \\
& Vumbura & -3.60 & 0.80 \\
& Moremi & -3.30 & 0.70 \\
D. mespiliformis & Boro & -1.20 & 0.21 \\
& Seronga & -1.97 & 0.49 \\
P. violacea & Vumbura & -0.43 & 0.25 \\
& Boro & -1.43 & 0.20 \\
& Santawani & -0.84 & 0.096 \\
A. nigrescens & Vumbura & -2.08 & 0.50 \\
& Boro & -1.74 & 0.30 \\
& Santawani & -0.064 & 0.00 \\
& Seronga & -2.19 & 0.65 \\
\hline
\end{tabular}

Philenoptera violacea (Klotzsch) Schrire showed an irregular size class distribution with some missing size classes indicating an unstable population in Boro (Figure 3A) and Santawani (Fig. 3B) while in Vumbura it showed a reverse $\mathrm{J}$ shaped size class distribution in which there were more individuals in the lower size than larger size classes (Fig. 3C). It showed a low negative slope coefficient value and $\mathrm{R}^{2}$ in Santawani indicating weak recruitment while in Boro it showed a relatively high negative slope coefficient but with low $\mathrm{R}^{2}$. Only in Vumbura were both the negative slope coefficient and $\mathrm{R}^{2}$ high indicating strong recruitment (Table 3 ).

D. mespiliformis showed a $\mathrm{U}$ shaped size class distribution with more individuals in the lower and higher size classes than in the middle size classes in Boro (Fig. 4A) and irregular size class distribution with some missing size classes in Seronga (Fig. 4B) and Vumbura (Figure $4 C)$. This indicates that $D$. mespiliformis populations in these two areas are unstable. They showed the lowest negative slope coefficient and $\mathrm{R}^{2}$, indicating weak recruitment in Vumbura while in Boro and Seronga it showed high negative slope coefficients indicating strong recruitment, although the $\mathrm{R}^{2}$ was low in both sites (Table 3).

Acacia nigrescens Oliv showed irregular size class distribution with some missing size classes indicating an unstable population in Boro (Fig. 5A) and Santawani (Fig. 5B). It showed a reverse J shaped size class distribution with more individuals in the lower size classes indicating a stable population in Seronga (Fig. 5C). A. nigrescens showed high recruitment in Boro and Seronga although for Boro the $\mathrm{R}^{2}$ was low. It showed a very low recruitment in Santawani with $\mathrm{R}^{2}$ of 0.00 indicating no correlation between diameter size class and the density of individuals (Table 3 ).
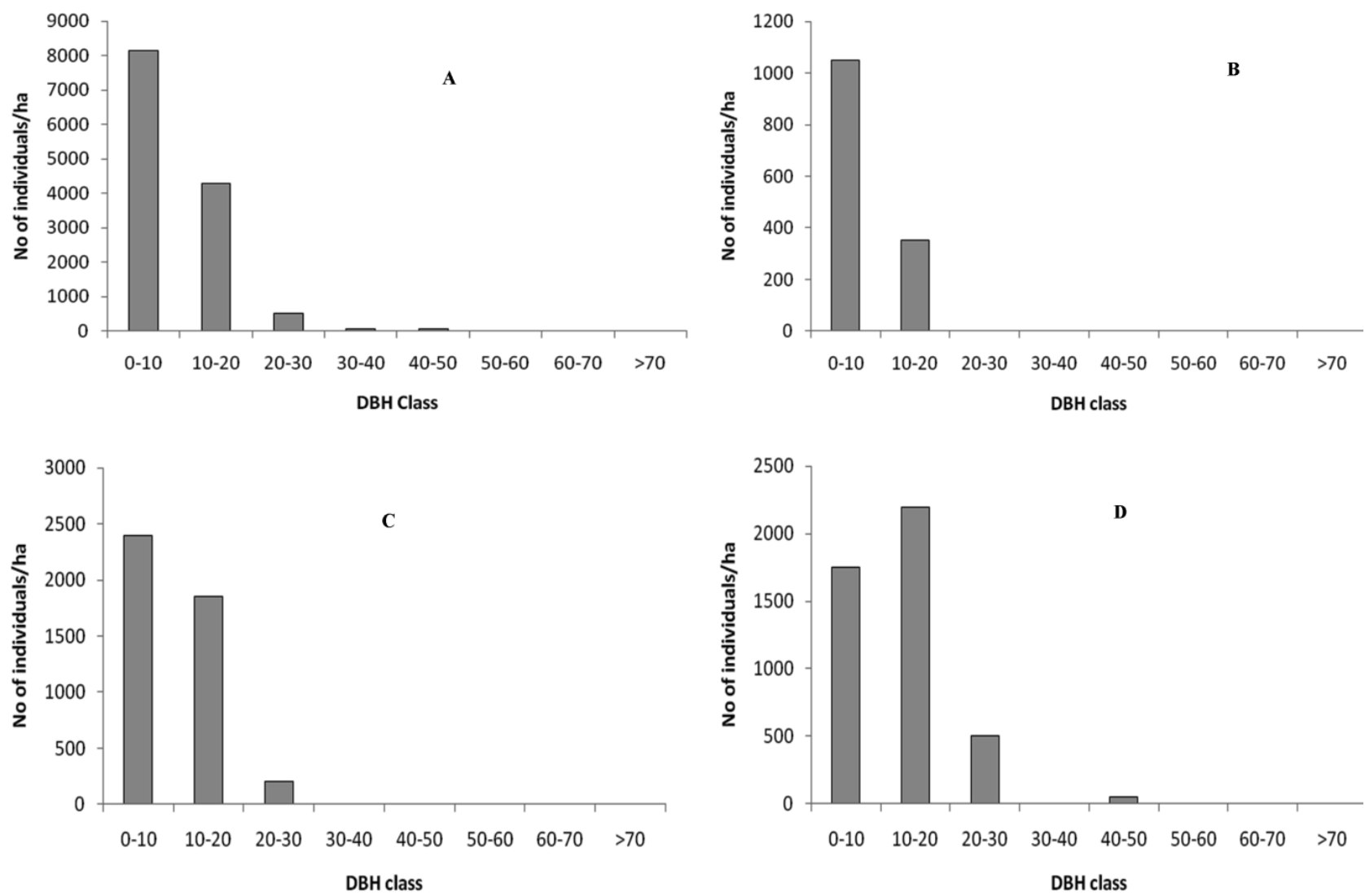

Fig. 2: Population size structure distribution of C. megalobotrys in Boro (A), Santawani (B), Vumbura (C) and Moremi Game Reserve (D). 

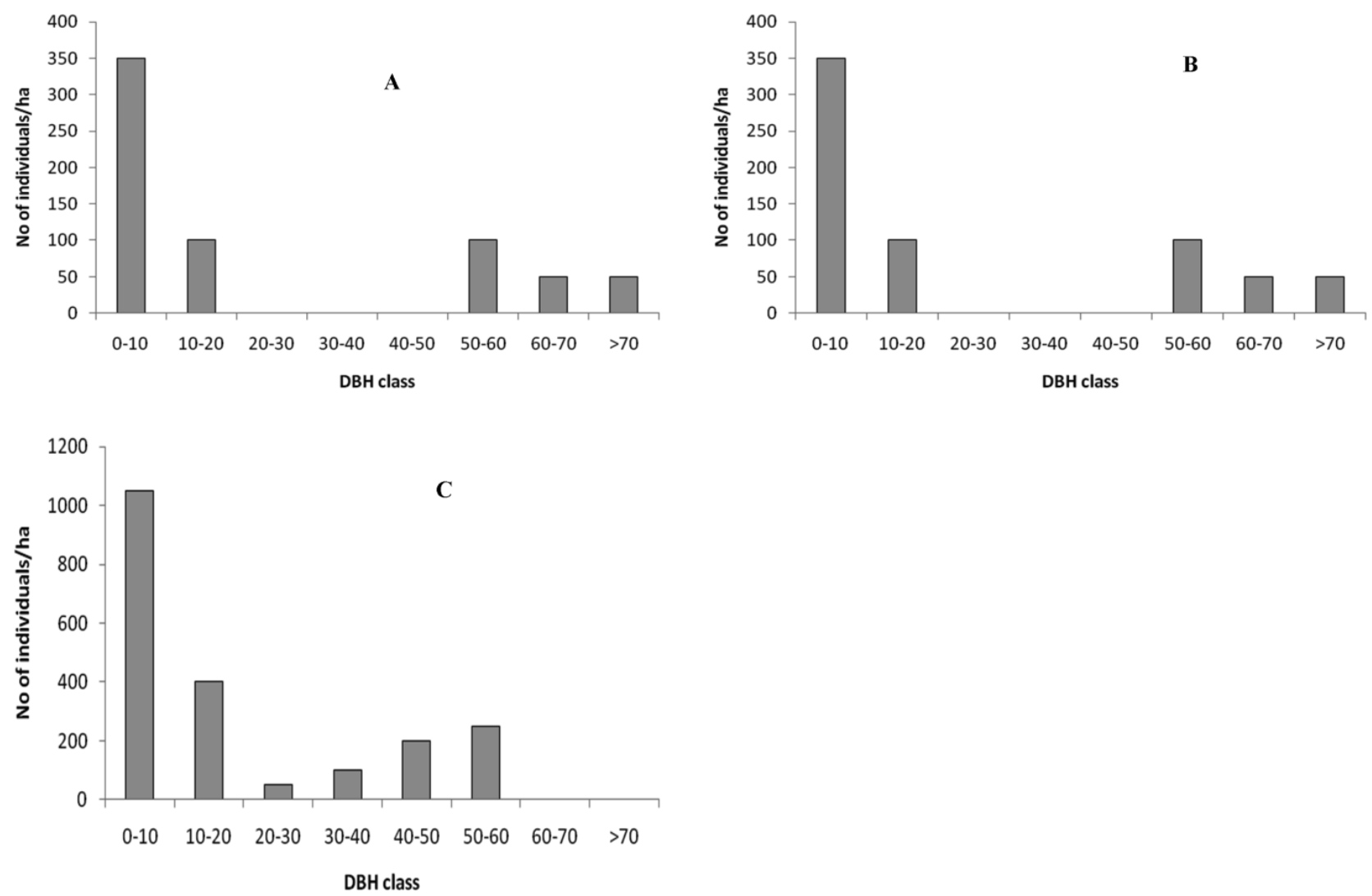

Fig. 3: Population size structure distribution of $P$. violacea in Boro (A), Santawani (B) and Vumbura (C).
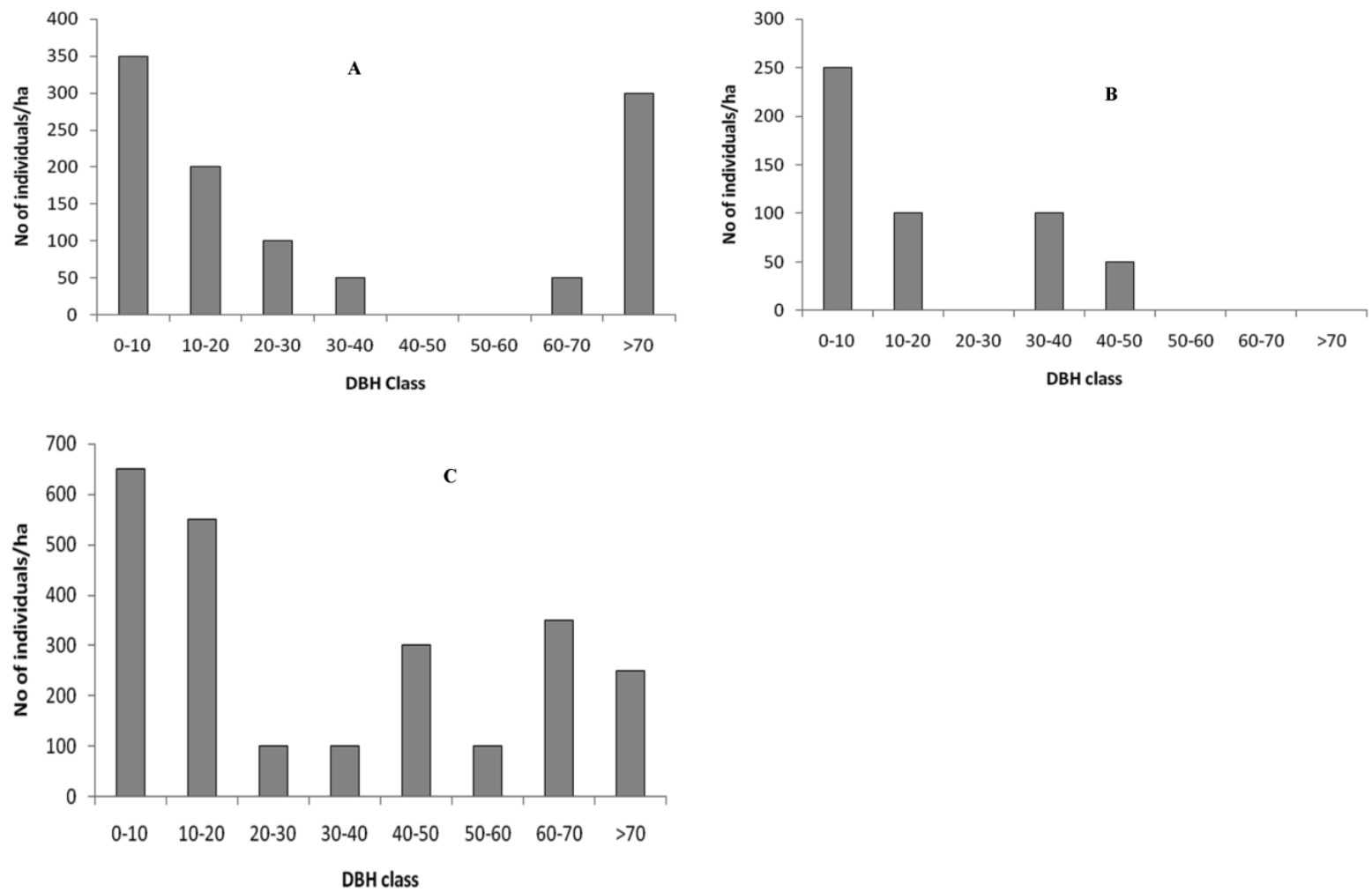

Fig. 4: Population size structure distribution of D. mespiliformis in Boro (A), Seronga (B) and Vumbura (C). 

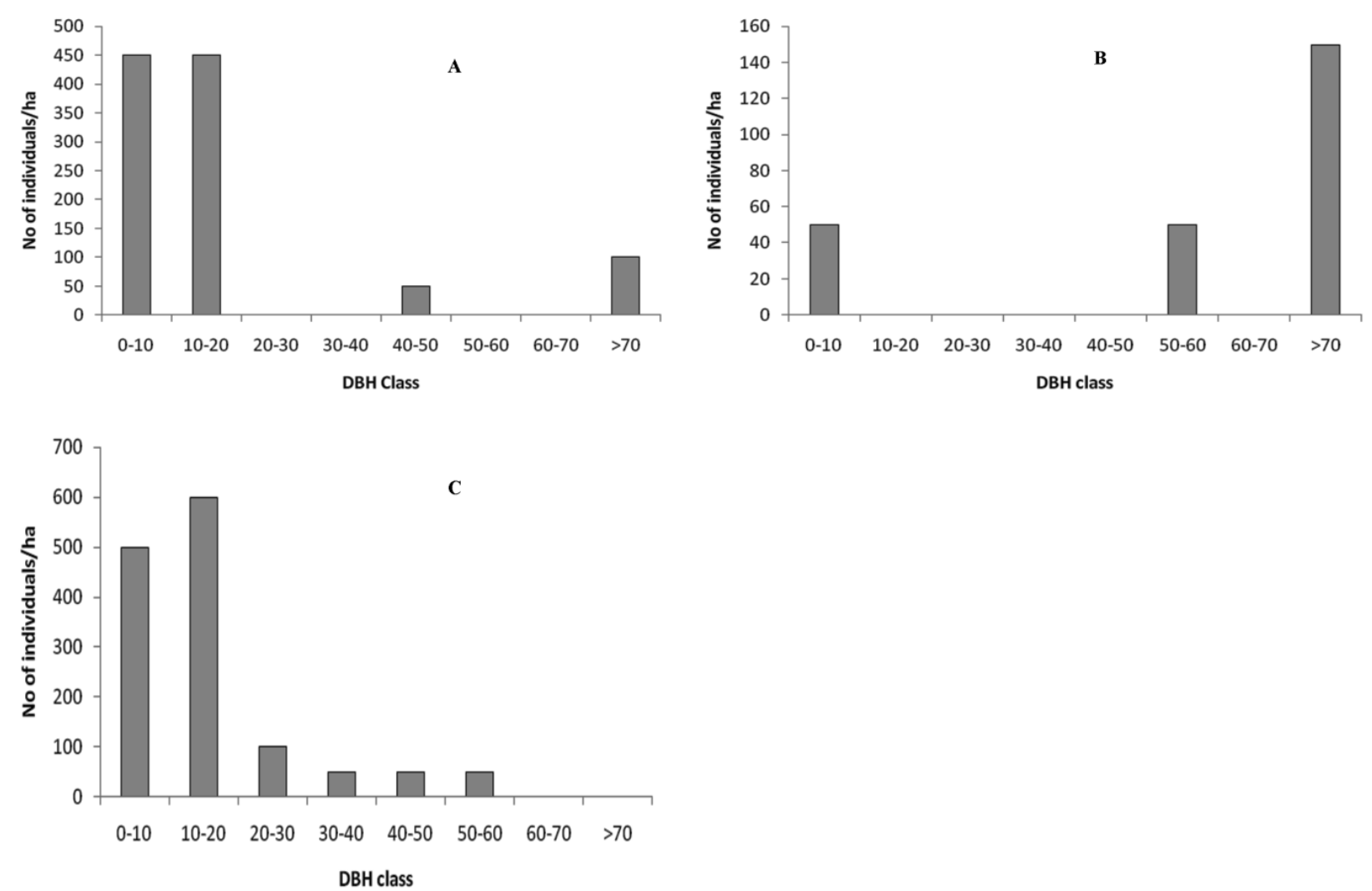

Fig. 5: Population size structure distribution of A. nigrescens in Boro (A), Santawani (B) and Seronga (C).

\section{Discussion}

The majority of sampled population had structures indicating ongoing recruitment. There was no significant difference between sites in terms of recruitment. Tree species showed spatial variation in their population size structure between different study sites. This variation could be due to differences in species reproductive strategy, competition, hydrology and disturbance from fire (Fi. 6) and elephant damage (Fig. 7). C. megalobotrys showed a reverse $\mathrm{J}$ shaped size class distribution indicating a stable population in Boro, Santawani and Vumbura with most individuals in the lower dbh class and few individuals in the higher classes. This could suggest that it has a high rate of germination but low recruitment. C. megalobotrys is an opportunistic species which colonizes floodplain margins and produces a large number seeds to enhance its survival through massive germination of seedlings. It also produces toxins in both leaves and seeds which renders it unpalatable to browsers to enhance its survival and recruitment of seedlings into large size classes (Hamandawana 2012).
However, not all of the germinated seedlings are recruited into the larger size classes as some die due to browsing by larvae of some butterflies (Ellery \& Ellery 1997). In Boro during this study C. megalobotrys individuals were observed stripped bare of leaves by caterpillars, stems bored by insects and seeds consumed by squirrels which apparently are resistant to the toxins.

Seed dispersal is an important component in tree population structure distribution (Hampe 2004). It allows seeds to reach suitable microsites for germination and establishment (Nathan \& MüllerLandau 2000). However, in some instances seeds could be dispersed in unsuitable habitats which could prevent their germination and establishment. Recruitment, establishment and survival of riparian tree species including $C$. megalobotrys are cited in literature to be influenced by the hydrological regime (Johnson 1994). As a typical R strategist (Hamandawana 2012), C. megalobotrys produces a large number of fruits which fall and germinate around the parent trees in large numbers. The species invests energy in a large food store, toxic shell and oils to maximize numbers of individuals in areas in which conditions may be suitable in the short term. Once established riparian tree species can also be threatened by excessive flooding which results in fatal anoxic conditions (Kozlowski 1984). Dead stands of C. megalobotrys probably due to waterlogging that resulted from the extensive flooding of 2011 were observed in Boro. These factors present survival and recruitment bottlenecks into larger size classes. This is consistent with Irvine and West (1979) who in the Escalante River, Utah, observed die-offs in riparian tree species due to periodic water fluctuation with severe flooding cited as the probable cause of tree mortality.

In Moremi Game Reserve the C. megalobotrys population size class distribution was bell shaped with fewer individuals in the lower and higher dbh classes than in the middle classes. This indicates an unstable population (Helm \& Witkowski 2012). High numbers of individuals in the middle classes could be due to an episodic recruitment event that could have occurred when the conditions were favourable (Hamandawana 2012). Generally the sites in Moremi Game Reserve were dry 


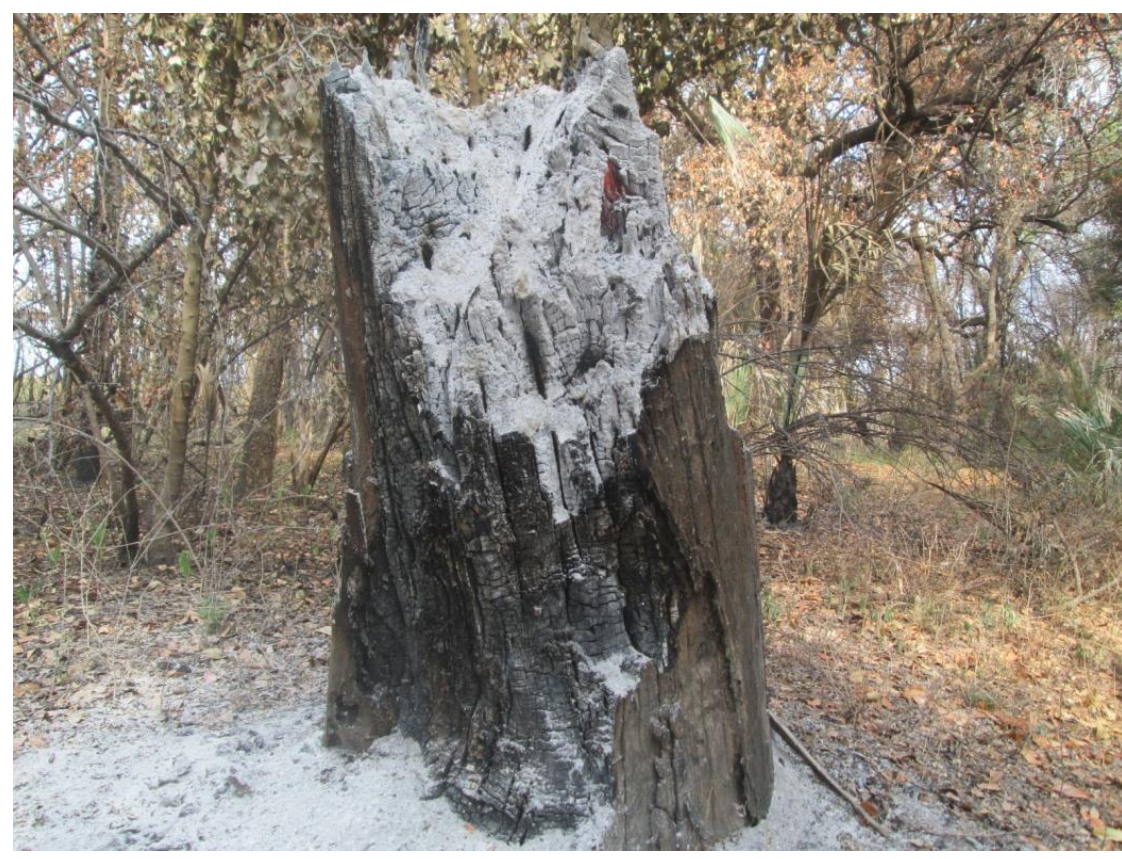

Fig. 6: Fire in the Okavango Delta influences riparian tree population size structure distribution.

during the field survey which might have prevented C. megalobotrys seed germination. Water from flooding or directly from rainfall is a germination requirement for activating metabolic processes required for a seed to germinate (Kozlowski 2002).

$P$. violacea and $A$. nigrescens showed irregular size class distribution in Boro and Santawani while D. mespiliformis was characterized by irregular size class distribution in Seronga and Vumbura. In both study sites $P$. violacea and $A$. nigrescens had some missing size classes while D. mespiliformis only showed missing size classes in Seronga. The missing size classes in $P$. violacea, A. nigrescens and $D$. mespiliformis could result from variable growth and unequal mortality rates in subsequent classes probably resulting from fire and elephant suppression (Hamandawana 2012). The current high elephant population density in the Okavango Delta is likely to result in the overexploitation of preferred species in a given size class (Skarpe et al. 2004).

Elephant-induced mortality of trees, suppressing recruitment of preferred tree species, has been reported elsewhere (e.g., Cumming et al. 1997, O'Connor et al. 2007). Along the Linyanti River in northern Botswana, $16 \%$ of dead A. nigrescens were killed by elephants with the remaining percentage probably due to other confounding factors such as wind and fire (Teren \& Owen-Smith 2010). The dbh size classes for the $16 \%$ mortality were not given. Giraffe browsing has also been cited as another factor leading to missing size classes in A. nigrescens (Teren \& Owen-Smith 2010). A. nigrescens also had more mature individuals than juveniles in Boro which suggests that it may be threatened by local extinction. Few individuals in the lower size classes in $A$. nigrescens are probably due to the inability of its seeds to reach suitable sites for germination and establishment. A. nigrescens produces seeds in pods which rely on water and wind for dispersal. If the flood water does not reach these seeds they cannot be dispersed to suitable germination sites and as a result they will remain dormant hence leading to few individuals in the lower size classes. If they germinate they will have to compete with the parent plant for survival. The same survival challenge could be faced by $P$. violacea which also produces its seeds in pods.

D. mespiliformis showed a $\mathrm{U}$ shaped size class distribution in Boro characterized by more individuals in the lower and higher dbh classes. High individuals in the larger and lower size classes could be due to episodic recruitment events that could have occurred when the conditions were favourable (Hamandawana 2012) and slowed down during the onset of unfavourable conditions for its establishment. Tree establishment may take place at intervals of many decades or centuries in response to prevailing moisture conditions (Young \& Lindsay 1988). In the Okavango Delta flooding dynamics could have an influence on riparian tree population size structure distribution. The quasi- cyclicity between multi-decadal wet and dry periods (Wolski et al. 2012) poses an episodic disturbance which may prevent the establishment of stable states in $D$. mespiliformis at Boro, instead inducing periods of high or low recruitment. This suggests that its population size structure distribution is driven by physical (allogenic) rather than autogenic processes (Baker \& Walford 1995).

Extremely low flooding conditions are capable of preventing the establishment of D. mespiliformis individuals in the middle size classes. In the years of relatively high floods when the water reaches the riparian zone, large stands of individuals in the lower size classes establish but do not reach maturity before they die in response to drying and elephant destruction. This may prevent individuals in the lower size classes from reaching later growth stages (Pettit \& Froend 2001). The larger size classes individuals of $D$. mespiliformis especially those with a dbh $>70 \mathrm{~cm}$ may have been recruited during the $1970 \mathrm{~s}$ period of more extensive, longer and deeper flooding and recruitment might have slowed down in the 1990s when the floods were low.

High numbers of individuals in the higher dbh classes could also be due to their resistance to elephant damage owing to their big size (Teren \& Owen-Smith 2010) while high numbers of individuals in the lower size classes could be attributed to its high germination rate (Zida 2009). D. mespiliformis grows in close proximity to surface water which exposes its seedlings to favourable soil and moisture conditions (Traore et al. 2013). D. mespiliformis also seems to attempt to maximize its germination and eventually establishment through production of edible fruits which are eaten by fish, birds and bats. The seeds of $D$. mespiliformis have been also observed in jackal dung (Heath \& Heath 2009). Thus this suggests that D. mespiliformis unlike C. megalobotrys invests reproductive effort in trying to establish new individuals in areas far from the parent to reduce competition for vital resources such as moisture, space and sunlight insolation. Pettit \& Froend (2001) discuss that there is need for seed fall to correspond with favourable site conditions in order to maximize their germination and establishment. In the Okavango Delta the seed fall in $D$. mespiliformis seems to be timed to correspond with optimum hydrological conditions which promote massive seedling germination. However, it also appears that 


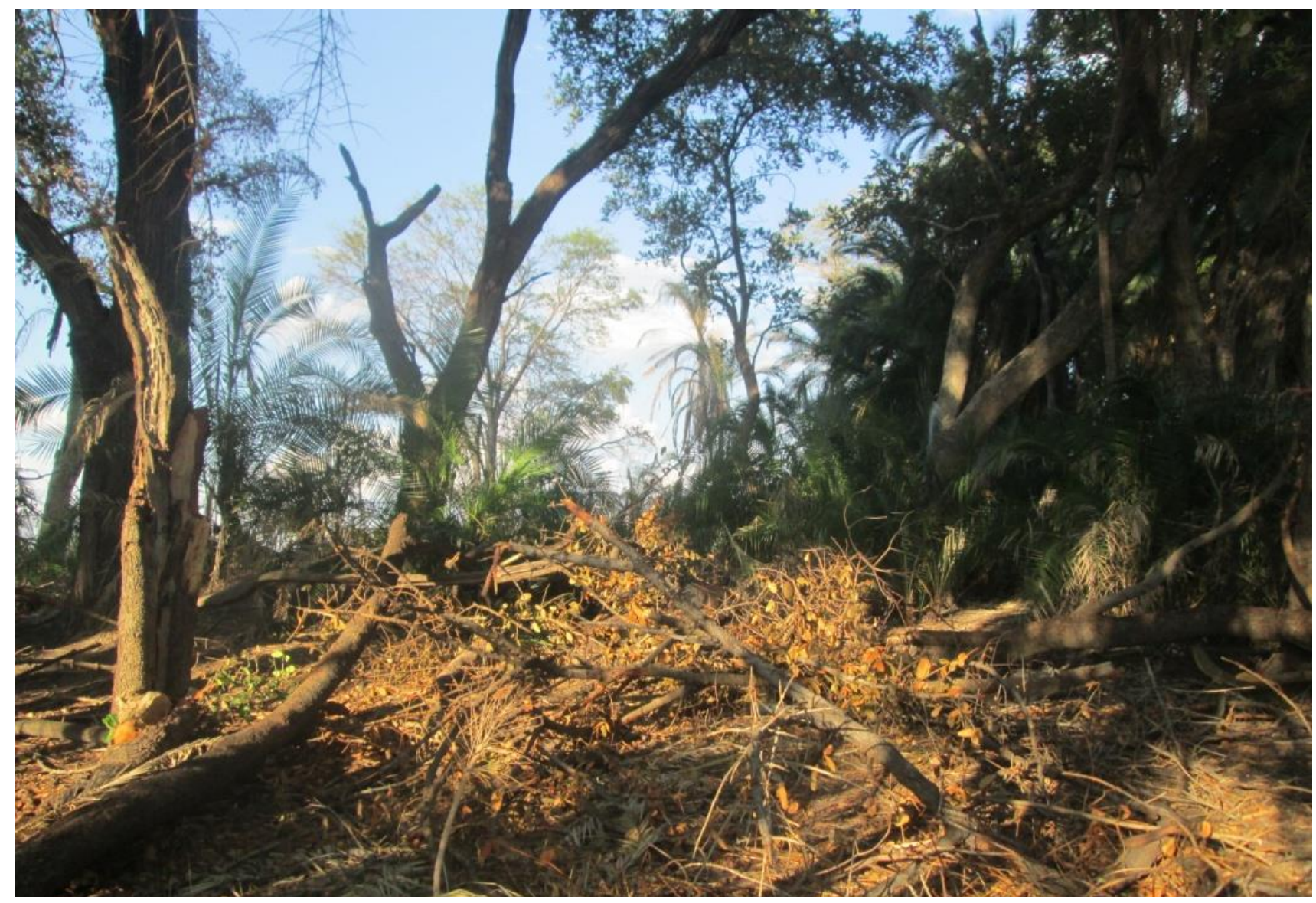

Fig. 7: Elephant damage in the Okavango Delta also influence riparian tree population size structure distribution in the Okavango Delta.

most of them are removed before they could reach the maturity stage.

Few individuals in the middle size classes of D. mespiliformis could result from constant browsing and grazing pressures (Gurmesa et al. 2012). This suggests that browsers and grazers particularly elephant prefer $D$. mespiliformis individuals belonging to the middle dbh classes which are likely to be more nutritious and easy to have access to than mature ones. Preference of mid-size class individuals of $D$. mespiliformis by elephant suggests that they are probably within their feeding height. Elephant damage was observed in Boro in which D. mespiliformis individuals in the middle dbh classes were heavily impacted. Continued foraging pressure on D. mespiliformis populations may prevent any individuals from reaching fruiting age. This species is already included in the Botswana red data and protected tree species list (Setshogo \& Venter 2003). The local loss of $D$. mespiliformis will also remove an important component of elephants and other herbivores' diet.

While elephant damage is a possible cause of variation of tree species population structure in the Okavango Delta it should be noted that there could be other confounding factors such as fire. Evidence of fire occurrence was observed during this study even though its actual year could not be established. Heinl et al (2007) found that the fire return interval in drier areas which encompass the riparian zone ranged between 7 and 8 years. Individuals found in the lower size classes could be within the fire trap which suppresses their recruitment into the larger size classes (Jacobs \& Biggs 2002). Lack of recruitment of individuals into the larger size classes will reduce the sexual reproduction of $P$. violacea, $D$. mespiliformis and A. nigrescens through a reduction in seed production. When the current individuals existing in the larger size classes eventually die, lack of seed input will result in their local extinction (Helm \& Witkowski 2012). Influence of fire on riparian tree species population structure was also observed in the Colorado River floodplain in which Tessaria sericea (Nutt.) Shinners was dominant after fire occurrence with Populus fremontii S. Watson completely excluded (Busch 1995). However, without further study it is not possible to attribute size-class distributional anomalies to the effects of fire in the Delta.

\section{Conclusions}

This is the first study of the population demographics of riparian trees in the Okavango Delta. The differences observed in recruitment patterns between sites are probably the result of a combination of hydrological factors with other environmental factors such as herbivory acting on both the germination and subsequent growth stages. Reproductive and successional strategies such as competition must be important drivers for the differences observed between species population structure within sites. This study clearly raises many new questions, including the primary one: what are the principal drivers of recruitment in riparian woodlands in the Delta? Questions related to this are: do different reproductive and dispersal strategies explain the variation we observe, or are major allogenic episodic events the main cause? How important is the role of the different scales of hydrological variation in stimulating or facilitating regenerative events?

Given the critical ecological function that the riparian woodland performs in the Delta, and the emerging understanding that riparian trees in other major tropical 
and sub-tropical wetland systems may fill similar roles, we consider further investigation of these questions a priority for land use and management authorities. In the short term interests of conserving tree diversity in the Delta, perhaps consideration should be given to the establishment of a number of strategically situated exclosures to remove the threat of elephant damage and provide nuclei for seed production and dispersal. We are currently involved in research aimed at designing a model of environmental controls of riparian tree species in the Okavango Delta. Future research should also focus on germination studies of the soil seed bank of these species to determine their regeneration potential.

\section{Acknowlegdements}

GT conceived the idea of the paper, did the field work, data analysis and write up. MM-H conceived the idea, helped in field work at Boro and write up. This work was conducted under The Future Okavango (TFO) Project, funded by the German Federal Ministry for Education and Research (BMBF). I would also like to acknowledge the assistance of Mr Mmusi Mmusi and Mr Wilfred Khaneguba during field work.

\section{References}

Baker, W.L., Walford, G.M. (1995): Multiple stable states and models of riparian vegetation succession on the Animas River, Colorado. - Annals of the Association of American Geographers 85: 320338. CrossRef

Björkvald, L., Boring, M. (2002): A minor field study of the infiltration rate on a floodplain in the Okavango Delta, Botswana. - MSc. thesis, Göteborg University [deposited in Göteborg University library].

Bonyongo, M.C., Mubyana, T. (2004): Soil nutrient status in vegetation communities of the Okavango Delta floodplains. South African Journal of Science 100: 337-340.

Busch, D.E. (1995): Effects of fire on Southwestern riparian plant community structure. - The Southwestern Naturalist 40: 259-267.

Carter, V. (1996): Wetland hydrology, water quality and associated functions. US Geological Survey Water Supply Paper 2425: 35-48.

Cronk, J.K., Fennessy, M.S. (2001): Wetland plants: Biology and Ecology. 1st edBoca Raton, Lewis Publishers. $\underline{\text { CrossRef }}$
Cumming, D.H.M., Feton, M.B., Rautebank, I.L., Taylor, R.D., Cumming, M.S., Dunlop, J.M., Ford, G.S., Hovorka, M.D., Johnston, D.S., Kalcounis, M.C., Mahlnga, Z., Portfors, C.V. (1997): Elephants, woodlands and biodiversity in miombo woodland in southern Africa. South African Journal of Science 93: 231-236.

Ellery, W.N. (1991): Water depth and biotic insulation: Major determinants of backswamp plant community composition. Wetlands Ecology and Management 1: 149-162. CrossRef

Ellery, W.N., Ellery, K., McCarthy, T.S. (1993): Plant distribution in Islands of the Okavango Delta, Botswana: Determinants and feedback interactions. African Journal of Ecology 31: 118-134. CrossRef

Gurmessa, F., Soromessa, T., Kelbessa, E. (2012): Structure and regeneration status of Komto Afromontane moist forest, East Wollega Zone, west Ethiopia. Journal of Forestry Research 23: 205216. CrossRef

Gumbricht T, McCarthy J, McCarthy TS (2004) Channels, wetlands and islands in the Okavango Delta, Botswana, and their relation to hydrological and sedimentological processes. - Earth Surface Processes and Landforms 29:15-29. CrossRef

Hamandawana, H. (2012): The impacts of herbivory on vegetation in Moremi game reserve, Botswana: 1967-2001. Regional Environmental Change 12: 15. CrossRef

Hampe, A. (2004): Extensive hydrochory uncouples spatiotemporal patterns of seedfall and seedling recruitment in a 'bird-dispersed' riparian tree. - Journal of Ecology 92:797-807. CrossRef

Heath, A., Heath R. (2009): Field guide to the plants of Northern Botswana including the Okavango Delta. - Kew, Royal Botanical Gardens.

Heinl, M., Frost, P., Vanderpost, C., Silva, J. (2007): Fire activity on dry lands and floodplains in the southern Okavango Delta, Botswana. - Journal of Arid Environment 68: 77-87. CrossRef

Helm, C.V., Witkowski, E.T.F. (2012): Characterising wide spatial variation in population size structure of a key stone savanna tree. - Forest Ecology and Management 263: 175-188. CrossRef

Hoffman, L.A., Redente, E.F., McEwen, L.C. (1994): Effects of selective seed predation by rodents on short grass establishment. - Ecological Applications 5: 200-208. CrossRef

Irvine, J.R., West, N.E. (1979): Riparian Tree Species Distribution and Succession along the Lower Escalante River, Utah. - The Southwestern Naturalist 24: 331-346. CrossRef

Jacobs, O.S., Biggs, R. (2002): The impact of the African Elephant on Marula trees in the Kruger National Park. - South Af- rican Journal of Wildlife Research 32: 13-22.

Jansen, R., Madzwamuse, M. (2003): The Okavango Delta Management Plan: The need for environmental partnerships. -In: Turton, A.R., Ashton, P., Cloete, E. [Eds]: Transboundary Rivers, Sovereignty and development: Hydropolitical Drivers in the Okavango River Basin, African Water Issues Research Unit (AWIRU) and Green Cross International (GCl), Pretoria and Geneva. 141-166.

Jones, R.H., Sharitz, R.R., Dixon, P.M., Segal, D.S., Schneider, R.L. (1994): Woody plant regeneration in four floodplain forests. - Ecological Monographs 64: 345-367. CrossRef

Kozlowski, T.T. (2002): PhysiologicalEcological impacts of flooding on riparian forest ecosystems. - Wetlands 22: 550-561. CrossRef

Lite, S.J., Bagstad, K.J., Stromberg, J.C. (2005): Plant species richness along lateral and longitudinal gradients of water stress and flood disturbance, San Pedro River, Arizona, U.S.A. - Journal of Arid Environments 6: 785-813. CrossRef

Matiza, T., Chabwela, H.N. [Eds.]: Wetlands conservation conference for Southern Africa. Proceedings of the Southern African Development Coordination Conference held in Gaborone, Botswana, 3-5 June 1991. IUCN, Gland, Swirtzerland [deposited at University of Botswana Library].

McCarthy TS, Ellery WN, Ellery K (1993) Vegetation-induced, subsurface precipitation of carbonate as an aggradational process in the permanent swamps of the Okavango (delta) fan, Botswana. Chemical Geology 107: 111-131. CrossRef

McCarthy, T., Ellery, W.N. (1994): The effect of vegetation on soil and ground water chemistry and hydrology of islands in the seasonal swamps of the Okavango fan, Botswana. - Journal of Hydrology 154: 169-193. CrossRef

McCarthy, J., Gumbricht, T., McCarthy T.S. (2005): Ecoregion classification in the Okavango Delta, Botswana from Multitemporal remote sensing. International Journal of Remote Sensing 26: 4339-4357. CrossRef

McCarthy, T.S., Humpries, M.S., Mahomed, I., Le Roux, P., Verhagen, B. Th. (2012): Island forming processes in the Okavango Delta, Botswana. - Geomorphology 179: 249-257. CrossRef

Murkin, H.R. (1998): Freshwater functions and values of Prairie wetlands. - Great Plains Research 8: 3-15.

Naiman, R.J., Décamps, H., Pollock, M. (1993): The role of riparian corridors in maintaining regional biodiversity. Ecological Applications 3: 209-212. CrossRef

Nathan, R., Müller-Landau, H.C. (2000): Spatial patterns of seed dispersal, their determinants and consequences for re- 
cruitment. - Trends in Ecology and Evolution 15: 278-285. CrossRef

Natural Resources and People, (2007): Okavango Delta management plan component 5 final report-wildlife Management-Human-Wildlife Conflict. Department of Wildlife and National parks, Ministry of Environment, Wildlife and Tourism, Gaborone, Botswana.

O'Connor, T.G., Goodman, P.S., Clegg, B., (2007): A functional hypothesis of local extirpation of woody plant species by elephant in Africa. - Biological Conservation 136: 329-345. CrossRef

Okavango Research Institute (2013): URL http://www.ori.ub.datacat $/$ modis.php?sc= okav. Accessed 2013/11/10.

Pettit, N.E., Froend, R.H. (2001). Variability in flood disturbance and the impact on riparian tree recruitment in two contrasting river systems. - Wetlands Ecology and Management 9: 13-25. CrossRef

Reddy, K.R., Gale, P.M. (1994): Wetland processes and water quality: A symposium overview. - Journal of Environmental Quality 23: 875-877. CrossRef

Ringrose, S., Matheson, W. (2001): Spatial characteristics of riparian woodlands in the distal Okavango Delta. - Botswana Notes and Records 33: 101-114.

Seavy, N.E., Gardali, T., Golet, G.H., Griggs, F.T., Howell, C.A., Kelsey R., Small, S.L., Viers, J.H., Weigand, J.F. (2009): Why climate change makes riparian restoration more important than ever: Recommendations for practice and research. - Ecological Restoration 27: 330-338. CrossRef

Setshogo, M.P., Venter, F. (2003): Trees of Botswana: names and distribution. Southern African Botanical Diversity Network Report No. 18. - Pretoria: Southern African Botanical Diversity Network.

Shackleton, C.M. (1993). Demography and dynamics of the dominant woody species in a communal and protected area of the eastern Transvaal Lowveld. South African Journal of Botany 59: 569-574.
Skarpe, C., Aarrestad P.A., Andreassen, H.P., Dhillion, S.S., Dimakatso, T., Du Toit, J.T., Halley, D.J., Hytteborn H., Makhabu S. (2004): The return of the giants: ecological effects of an increasing elephant population. - Ambio 33: 276-282. CrossRef

Sop, T.K., Oldeland, J., Schmiedel, U., Ouedraogo, I., Thiombiano, A. (2011): Population structure of three woody species in four ethnic domains of the sub-sahel of Burkina Faso. - Land Degradation and Development 22: 519-529. CrossRef

Sullivan, P., Price, R.M., Ross, M., Scinto, L., Stoffella, S., Cline, E., Dreschel, T., Sklar, F. (2010): Hydrologic processes on tree islands in the Everglades (Florida, USA): tracking the effects of tree establishment and growth. - Hydrogeology Journal 19: 367-378. CrossRef

Teren, G., Owen-Smith, N. (2010): Elephants and riparian woodland changes in Linyantiregion, northern Botswana. Pachyderm 47: 18-25.

Traoré, S., Tigabu, M., Ouédraogo, S.J., Boussim, J.I., Guinko, S., Lepage, M.G. (2008): Macrotermes mounds as sites for tree regeneration in a Sudanian woodland (Burkina Faso). - Plant Ecology 198: 285-295. CrossRef

Traoré, L., Sop, T.K., Dayamba, S.D., Traoré, S., Hahn, K., Thiombiano, A. (2013): Do protected areas really work to conserve species? A case study of three vulnerable woody species in the Sudanian zone of Burkina Faso. Environmental Development Sustainability 15: 663-686. CrossRef

Walker, J., Robertson, J.A., Penridge, L.K., Sharpe, P.J.H. (1986): Herbage response of tree thinning in Eucalyptus crebra woodland. - Australian Journal of Ecology 11: 135-140. CrossRef

Wetzel, P.R., Valk, A.G.vd., Newman, S., Gawlik, D.E., Gann, T.T., CoronadoMolina, C.A., Childers, D.L., Sklar, F.H. (2005): Maintaining tree Islands in the Florida Everglades: Nutrient redistribution is the key. - Frontiers in Ecology and the Environment 3: $370-376$ CrossRef

Wilson, B.H., Dincer, T. (1976): An introduction to the hydrology and hydrography of the Okavango Delta. Proceedings of the symposium on the Okavango Delta and its future utilization held in Gaborone, Botswana. Botswana Society, Gaborone.

Van der Valk, A. (2006): The biology of freshwater wetlands. 2nd ed- New York, Oxford University press.

Wolski, P., Savenije, H.H.G., MurrayHudson, M., Gumbricht, M. (2006): Modelling of the flooding in the Okavango Delta, Botswana, using a GIS model. - Journal of Hydrology 331: 58-72. CrossRef

Wolski, P., Todd, M.C., Murray-Hudson, M.A., Tadross, M. (2012): Multi-decadal oscillations in the hydro-climate of the Okavango River system during the past and under a changing climate. - Journal of Hydrology 475: 294-305. CrossRef

Young, T.P., Lindsay, W.K. (1988): Role of even-age population structure in the disappearance of Acacia xanthophloea woodlands. - African Journal of Ecology 26: 69-72. CrossRef

Zida, M., Tigabu, M., Sawadogo, L., Tiveau, D., Odén, P.C. (2009): Longterm effects of prescribed early fire, grazing and selective tree cutting on seedling population in the Sudanian savanna of Burkina faso. - African Journal of Ecology 47: 97-108. $\underline{\text { rossRef }}$

\section{Affiliations}

Gaolathe Tsheboeng*

(gtsheboeng@ tati.ub.bw), Mike MurrayHudson (mmurray-hudson@ori.ub.bw)

Okavango Research Institute

University of Botswana

P/Bag 285

Maun, BOTSWANA

*Corresponding author 